\title{
Applying a New Management Model in the Joint Staff: An Executive Summary
}

\author{
Francois Melese *
}

\section{Introduction}

Agencies throughout the federal government face the same basic set of management challenges: accountability, or tracking government spending on inputs; efficiency, or minimizing the costs of government activities; and effectiveness, or measuring outputs/outcomes and tying budgets to performance. A key objective in shifting government's focus from inputs to activities/outputs is to promote more robust cost-effectiveness analyses to improve agency investments and support Congressional decision making. ${ }^{1}$

The challenge is that, at best, most Department of Defense (DoD) accounting systems track expenditures on inputs. Many were neither designed nor intended to report expenditures by activities or outputs. This challenge is especially acute for activities that cut across military services, like the Chairman of the Joint Chiefs of Staff's Joint Exercise Program (JEP). To assist the Joint Staff to address these challenges, an ongoing project commissioned by the Joint Staff Comptroller leverages a new integrated public management model called the "Super-Unified Customer and Cost Evaluation Strategic System" (SUCCESS). ${ }^{2}$ Guided by SUCCESS, the J7/JEP and Joint Staff Comptroller teams are currently integrating and mapping U.S. Air Force, Navy, and Army data by individual exercise. This ongoing initiative is building a foundation for future analysis and evaluation of the efficiency and effectiveness of joint exercise activities.

Resting on fundamental micro-economic and accounting principles, SUCCESS integrates three widely used business management frameworks that underpin many

* Dr. Francois Melese is a Professor of Economics in the Defense Resources Management Institute at the U.S. Naval Postgraduate School in Monterey, CA. He would like to thank the Joint Staff Comptroller and J7/JEP team for their patience in guiding him through the intricacies of the Joint Exercise Program. Any errors or omissions are solely the responsibility of the author, and the usual disclaimers apply. A version of this article previously appeared as Francois Melese and D. Savage, "SUCCESS: Applying a New Management Model in the Joint Staff," Armed Forces Comptroller 53:1 (Winter 2008): 33-38.

Chief Financial Officers Act (1990 CFO Act), and Government Performance and Results Act (1993 GPRA).

2 Francois Melese, James Blandin, and Sean O'Keefe, “A New Management Model for Government: Integrating Activity-Based Costing, the Balanced Scorecard and Total Quality Management," The International Public Management Review 5:2 (2004): 103-30; available at www.ipmr.net. 
commercial Enterprise Resource Planning (ERP) ${ }^{3}$ applications, together with the Planning, Programming, and Budgeting System (PPBS). These include:

- Activity-Based Costing (ABC) ${ }^{4}$

- The Balanced Scorecard (BSC) ${ }^{5}$

- Total Quality Management (TQM: Lean, Six Sigma, etc.), captured here primarily through the Shewhart-Deming "PLAN-DO-CHECK-ACT" cycle of continuous improvement (PDCA). ${ }^{6}$

PPBS was originally designed as a high-level management information system to facilitate constrained optimization to achieve a form of "allocative efficiency" within DoD - that is, to maximize national security subject to fiscal constraints. As originally conceived, PPBS was meant to assist senior defense officials to establish activity/ output (or "capability") priorities within the budget, and to shift financial resources and guide investments among defense programs - and across the military services - from less to more productive uses in response to changes in the national security environ-

3 A descendent of the management information systems (MIS) and Material Resource Planning (MRP) movements, Enterprise Resource Planning (ERP) was initially led by SAP, a German software company. Today, multiple suppliers including IBM, Microsoft, PeopleSoft, Baan, Seibel, and others offer ERP applications designed to streamline and integrate operation processes and information flows in a company to increase productivity and cut costs. These customized software solutions apply the latest database, reporting and analysis tools in an attempt to measure, monitor and integrate various functional areas like manufacturing, sales and marketing, distribution, customer service, accounts payable/receivable, purchasing, inventory and material planning, human resources, financial accounting, asset management, project scheduling, etc.

4 See H. Thomas Johnson and Robert S. Kaplan, Relevance Lost: The Rise and Fall of Management Accounting (Boston: Harvard Business School Press, 1987); James A. Brimson and Callie Berliner, eds., Cost Management for Today's Advanced Manufacturing (Boston: Harvard Business School Press, 1988); and Steve Player and Carol Cobble, Cornerstones of Decision Making: Profiles of Enterprise ABM (Greensboro, NC: Oakhill Press, 1999).

5 See Robert Kaplan and David Norton, "The Balanced Scorecard: Measures that Drive Performance," Harvard Business Review (Jan.-Feb. 1992): 71-80; Kaplan and Norton, "Using the Balanced Scorecard as a Strategic Management System," Harvard Business Review (JanFeb 1996): 75-85; Kaplan and Norton, The Balanced Scorecard (Boston: Harvard Business School Press, 1996); and Kaplan and Norton, The Strategy Focused Organization (Boston: Harvard Business School Press, 2001).

6 See W. Edwards Deming, Out of Crisis (Cambridge, MA: M.I.T. Center for Advanced Engineering Study, 1986); and Peter Senge, "Looking Ahead: Implications of the Present," Harvard Business Review (Sept.-Oct. 1997): An important consequence of the PDCA cycle through SUCCESS is that it emphasizes continuous monitoring and evaluation of customerdriven measures of performance, along with costs/budgets, to reveal returns on investments. This results in an ongoing evaluation of planned vs. actual budgets and planned vs. actual performance/effectiveness, which completes the closed-loop feedback cycle built into SUCCESS. 
ment. ${ }^{7}$ As one Department of Defense report put it, "The ultimate objective of PPBS shall be to provide ... operational commanders-in-chief the best mix of forces, equipment and support attainable within fiscal constraints." 8

Today, a new emphasis on "execution" is reflected in a new name: PPBE. A "capabilities-based" PPBE process is currently being implemented to make high-level defense resource allocation decisions for DoD that culminate in the annual defense budget submitted by the President to Congress. SUCCESS offers a lower-level integrated public management model that supports this effort and captures the spirit of PPBE.

SUCCESS was first applied to generate fresh insights into two ongoing U.S. federal management initiatives: the Congressionally-mandated "Government Performance and Results Act" (GPRA), and the "President's Management Agenda." Subsequently, SUCCESS provided a conceptual model that helped guide the development and evaluation of the new PPBE process in DoD's latest Quadrennial Defense Review (QDR). ${ }^{10}$

This executive summary reviews a longer study that reports on an ongoing pilot program initiated by the Joint Staff Comptroller to implement the SUCCESS framework to support J7 (Operational Plans \& Interoperability) in managing the Chairman of the Joint Chiefs of Staff's two-hundred-million-dollar "Joint Exercise Program" (JEP). ${ }^{11}$ The success of this effort could serve as a template for other organizations in the Joint Staff and throughout the Department of Defense. The next sections introduce SUCCESS and offer a brief background and review of the model through its application to the Joint Staff's Joint Exercise Program.

\section{Leveraging SUCCESS and PPB to Study the Joint Exercise Program (JEP)}

The Joint Staff's FY 2008 Budget Highlights describes the Joint Exercise Program (JEP) as "the Chairman and Combatant Commanders' principal vehicle for achieving joint and multinational training."12 In a section of the latest QDR entitled "Build the Right Skills," the focus is on "[m]aintaining the capabilities required to conduct effective multi-dimensional joint operations [including] battlefield integration with interagency partners and combined operations - the integration of the joint force and coalition forces...."13

7 Allen Schick, "The Road to PPB: The Stages of Budget Reform," Public Administration Review (December 1966).

8 Department of Defense Document 7045.14 (22 May 1984).

9 See Melese, Blandin, \& O'Keefe, "A New Management Model for Government."

10 QDR Integrated Product Team (IPT) \#5 Meeting, Pentagon, Washington, D.C., 2005; Donald Rumsfeld, Quadrennial Defense Review (QDR) Report (Washington, D.C.: Office of the Secretary of Defense, 6 February 2006).

11 A full version of the report is available upon request from the author, at fmelese@nps.edu.

12 Joint Staff Comptroller, "The Joint Staff, FY 2008 Budget Highlights," (March 2007), 19.

13 Donald Rumsfeld, Quadrennial Defense Review (QDR) Report, 77. 
The Joint Education and Training Division of J7 (Operational Plans \& Joint Force Development) manages JEP. The Joint Staff's exercise budget funds only the transportation of personnel and equipment to worldwide exercises. J7 manages the strategic transportation program, while the Joint Staff Comptroller is responsible for funding strategic lift for the exercises. At the level at which $\mathrm{J} 7$ operates, the key players are:

- The Combatant Commanders (COCOMs)

- The U.S. Transportation Command USTRANSCOM, which includes the Air Mobility Command (AMC), the Military Sealift Command (MSC), and the Surface Deployment and Distribution Command (SDDC)

- The branches of the armed services

- J7/JEP

- The Joint Staff Comptroller.

Figure 1 illustrates the relationships of each of these key players within the context of the SUCCESS model. It also reveals key linkages between PPBS and SUCCESS as it applies to JEP.

The different responsibilities and perspectives of each key player (COCOM, USTRANSCOM, and J7) are reviewed and interpreted below in the context of the SUCCESS model illustrated in Figure 1. Applying the PPBS Cycle described in JEP's "Coordination Procedures" offers valuable insights in the context of SUCCESS. ${ }^{14}$

\section{Planning}

The first loop through the SUCCESS process is launched with a planning phase, where defense planning and fiscal guidance prompts a review by COCOMs of their missions, goals, and objectives for JEP. That is, this is the phase where COCOMs determine what it is they will do. The Customers in this context are the COCOMs who have a derived demand for strategic lift to support their planned exercises.

\section{Programming}

The subsequent "do" phase in SUCCESS corresponds to the programming phase in PPB. In this phase, organizations review existing activities and identify incremental adjustments and investments in their processes and/or products (capabilities), in order to "supply" services that respond to the planning guidance. In short, if the planning phase identifies "what to do," the programming phase outlines "how to do it." For JEP, the production and supply of strategic lift is largely in the hands of USTRANSCOM. They combine available inputs (military aircraft, ships, commercial charters, etc.) to produce strategic lift outputs (transport capabilities) required by the COCOMs.

14 Chairman of the Joint Chiefs of Staff Manual, J-7, Joint Training Manual for the Armed Forces of the United States, CJCSM 3500.03A (1 September 2002), Enclosure L. 


\section{SUCCESS: Planning, Programming \& Budgeting Strategic Lift (J-7/JEP) \\ Planning Programming}

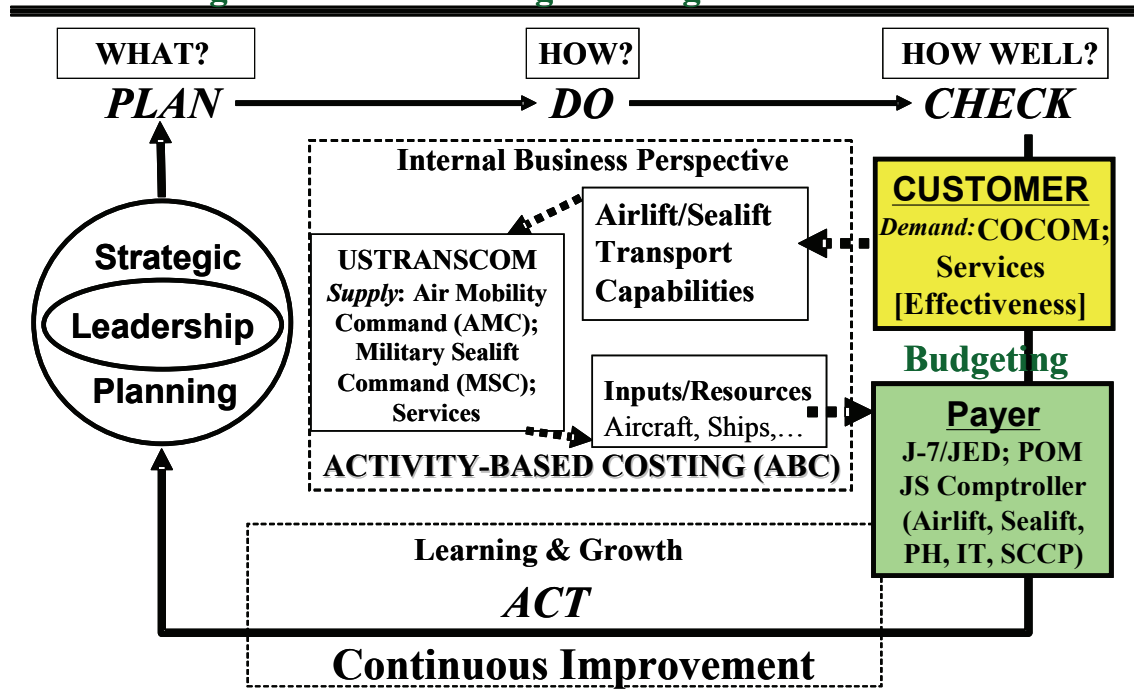

Figure 1: SUCCESS for JEP—A PPB Perspective

\section{Budgeting}

The "check" phase in the first loop through SUCCESS requires organizations to develop budget estimates that are eventually rolled up into the Program Objectives Memoranda (POM) of the services, defense agencies, and Joint Staff. After being vetted at different levels, these program proposals ultimately find their way into defense budget estimates included as budget estimate submissions (BES) in the President's defense budget submitted to Congress. The estimated input costs for JEP make up the strategic transportation budget that is the primary responsibility of $\mathrm{J} 7$ and the Joint Staff Comptroller.

\section{New Insights from Activity-Based Costing (ABC)}

The first step in applying Activity Based Costing/Budgeting (a key pillar in the "do" phase of SUCCESS) to the Joint Exercise Program is to recognize that the "activities" being considered are joint exercises. The next step is to recognize the three distinct perspectives of the three key players. The perspectives of the COCOM (customer), J7 (payer), and USTRANSCOM (producer/supplier) are illustrated in Figure 2 as three matrices (of activities on inputs) in the context of the first (PPB) loop through SUCCESS. Cascading down these matrices reveals the "planned budget" for strategic lift for the Joint Exercise Program. 


\section{J-7/JEP Data Transparency: PLANNED}

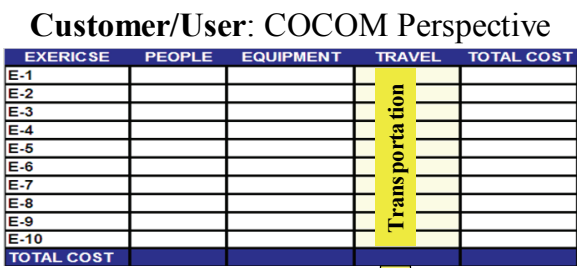

\section{First Loop $\underline{\text { PPB }}=$ PLANNED Budget}

Payer: J-7/JEP Perspective

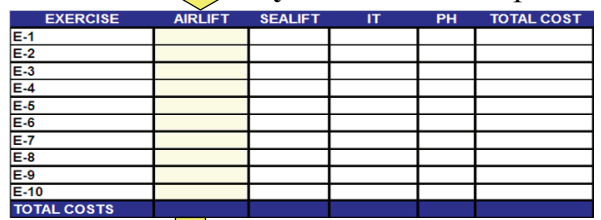

Supplier: USTRANSCOM (AMC) Perspective

\begin{tabular}{|c|c|c|c|c|c|c|c|c|c|c|c|c|}
\hline EXERCISE & $c-130$ & $c-141$ & c. 5 & $c-1$ & KC- & & KC- -135 & $\begin{array}{c}\text { COMLERCIAL } \\
\text { COST }\end{array}$ & $\begin{array}{l}\text { CHANNEL } \\
\text { CARGO }\end{array}$ & $\begin{array}{r}\text { ALFF COST } \\
\text { (SUB-TOTAL) }\end{array}$ & $\begin{array}{l}\text { COMMERCIAL } \\
\text { MCKETAUTH }\end{array}$ & GRAND TOTAL \\
\hline $\begin{array}{l}E-1 \\
E-2\end{array}$ & & & & & & & & & & & & \\
\hline & & & & & & & & & & & & \\
\hline & & & & & & & & & & & & \\
\hline 5 & & & & & & & & & & & & \\
\hline 䐴 & & & & & & & & & & & & \\
\hline-8 & & & & & & & & & & & & \\
\hline & & & & & & & & & & & & \\
\hline OTAL COSTS & & & & & & & & & & & & \\
\hline
\end{tabular}

Figure 2: Planned Budget Perspectives for COCOM, J7, and USTRANSCOM

\section{COCOM Perspective}

The first and highest level ("Effectiveness") perspective is that of the COCOM customers. Any attempt to increase effectiveness at this level involves an (implicit) constrained optimization: maximizing joint and combined troop capabilities through training exercises, subject to fiscal constraints. The solution requires an evaluation of the marginal benefits and costs of expanding (or funding) one exercise relative to another. This requires estimating the total costs of an exercise and combining this data with some measure of effectiveness for each exercise. Note that in the top matrix of Figure 2, the strategic lift (transportation) column of the total costs of an exercise is a J7 and Joint Staff Comptroller responsibility. The total strategic lift budget for a given year is simply the sum of the entries in that column. The current J7/JEP-SUCCESS initiative involves an effort to combine and integrate data across the services to facilitate the collection of strategic lift cost data by exercise. The top matrix in Figure 2 offers the Joint Staff a way to focus on how J7's efforts might contribute to and facilitate a higher level of optimization. The challenge is to combine timely, accurate, and complete strategic lift cost data with other joint exercise costs (personnel, equipment, etc.) to support cost-effectiveness evaluations of joint exercises to globally optimize force capabilities. 


\section{J7/JEP Perspective}

The second, lower-level perspective is also the most relevant to $\mathrm{J} 7$ and the Joint Staff Comptroller. The middle matrix in Figure 2 breaks strategic lift into its various components. In order to identify the strategic lift costs of each exercise, J7/JEP must capture the complete costs of airlift, sealift, inland transportation, port handling, etc. across all the services involved in a particular exercise. To complete the cells of this matrix and build a budget for strategic lift, J7 must first obtain estimates from the COCOMs of the number of passengers (\#pax) and amount of cargo to be transported to support their joint exercises. Cost estimates can be generated by multiplying the expected number of passengers and amount of cargo by a forecast of an average total (unit) cost or price per passenger or cargo mile ( $\$ /$ passenger $/ \mathrm{mile}$ or $\$ /$ cargo/mile) obtained from USTRANSCOM. ${ }^{15}$

To improve cost transparency in the management of joint exercises, accounting systems need to report total costs of program inputs (CTP, airlift, sealift, inland transportation, port handling, etc.) by individual exercise. ${ }^{16}$ Some initial results of J7's data collection efforts are illustrated in Figure 3.

Where can $J 7$ get its biggest return from efficiencies?

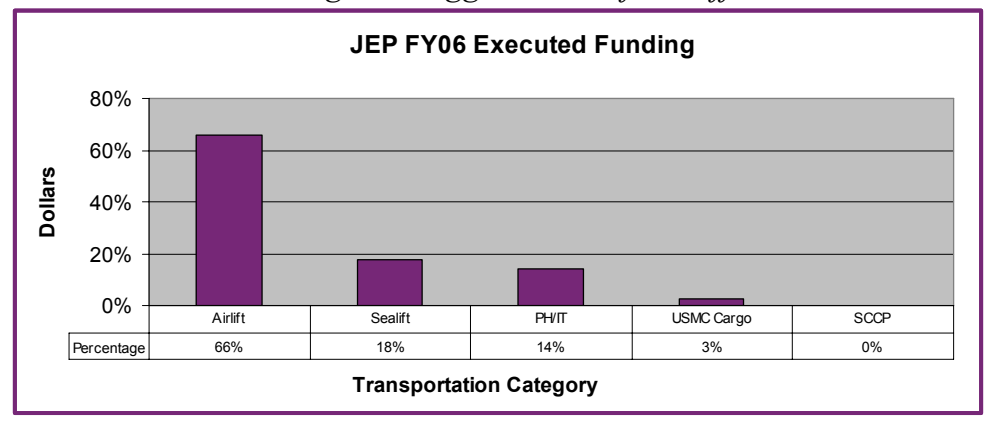

Figure 3: Total Costs by Transportation Category

15 Recent dramatic increases in revolving fund rates (a 5.2 percent increase for FY2007, followed by a 44.4 percent increase for FY2008) pose a significant challenge for efforts to forecast future JEP costs/budgets. See President's Budget 2/2007 for 2008-09, United States Air Force Working Capital Fund (WCF), Fiscal Year 2008/2009 Budget Estimates Overview (February 2007), 83; available at http://www.saffm.hq.af.mil/shared/media/document/AFD070209-054.pdf.

16 Some accounting systems currently report at the "program" input level, but mostly not by exercise. OSD reports at the highest level: CIF, ORF, \& Misc. Services (the category that includes JEP). The military services report at a lower level, breaking Misc. Services into: CTP, $\mathrm{PH}$, IT, etc., but most only report totals not broken down by individual joint exercise. 
The costs illustrated in Figure 3 roughly correspond to the total cost categories distributed along the bottom row of the middle matrix in Figure 2. Examining the distribution of these costs over the different strategic lift components, it is clear that in FY2006 over 80 percent of the strategic lift budget could be attributed to airlift and sealift. In fact, over 60 percent of the budget is due to airlift alone.

Given the importance of airlift in the overall JEP budget, Figure 4 reveals the various components (inputs) that make up airlift. It is clear from the data collected for FY2006 that commercial charter is by far the largest component of airlift costs. It is also the largest single component of overall spending on strategic lift. Whereas Figure 3 reflects J7/JEP's perspective, Figure 4 is more in line with USTRANSCOM's perspective.

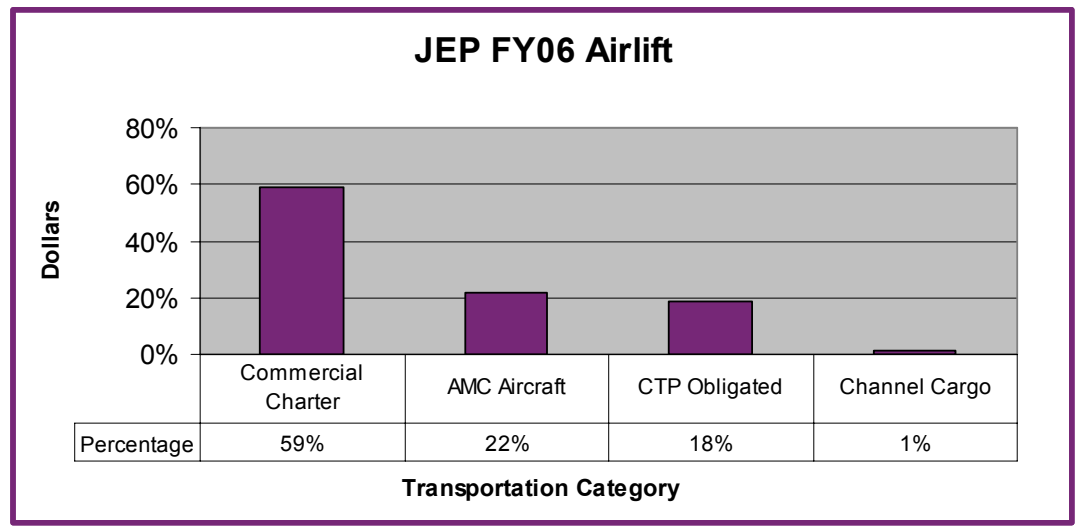

Figure 4: Total Costs of Airlift by Category

\section{USTRANSCOM (AMC) Perspective}

Returning to Figure 2, the bottom matrix breaks airlift into its various components (similar to Figure 4). This Activity-Based Costing/Budgeting matrix for one activityairlift - illustrates the perspective of USTRANSCOM's Air Mobility Command (AMC). This input-activity matrix offers an opportunity to identify more efficient substitution possibilities in the "internal business" (production function) component of SUCCESS (see Figure 1).

Similar matrices could be constructed for sealift from the perspective of USTRANSCOM's Military Sealift Command (MSC) and the Surface Deployment and Distribution Command (SDDC). The constrained optimization problem facing USTRANSCOM is how to choose an optimum mix of airlift assets that minimizes the costs of satisfying transportation demands for each exercise. But this requires AMC to have data that reveal alternative possible mixes (technical efficiency, or the production function), and that supports an evaluation of those alternatives in the optimization (economic efficiency, or cost minimization). This is one of the desired outcomes of the 
ongoing J7/JEP-SUCCESS project. Another opportunity uncovered by the project is for more timely submissions by the COCOMs of accurate demand forecasts, which would increase the ability of the AMC to put commercial contracts out to competitive bid, which would in turn lower the overall costs of airlift.

\section{Leveraging SUCCESS+PPBE for JEP}

Historically, PPBS emphasized the equivalent of the preliminary (Planning, Programming, and Budget estimation) loop through SUCCESS (depicted in Figure 1). In 2002, two major modifications to PPBS occurred. ${ }^{17}$ First, a shift to a two-year cycle was implemented. Second, an "execution" phase was added. The name was changed to PPBE to reflect the new emphasis on budget "execution" and the "evaluation" of results. ${ }^{18}$ The recent change to a two-year cycle in the PPBE process roughly corresponds to two loops through the SUCCESS model illustrated in Figure 1.

\section{Execution and Evaluation}

The first loop of the PPB cycle illustrated in Figure 1 results in a "planned budget" submitted to Congress. After extensive review, Congress passes defense budget authorization and appropriation bills that become law. These laws grant DoD "obligation authority" stating the maximum dollar amount of contracts, etc. that can be entered into in the budget year. The passage of these bills launches a second loop through SUCCESS. Whereas the first loop through SUCCESS (Figure 1) has a Planning, Programming, and Budget estimation/forecasting focus, the second loop involves actual "execution"- converting inputs into outputs, or spending the defense budget on transporting troops, equipment, etc.-and "evaluation"-producing transportation and training capabilities and evaluating outcomes.

Working back up the three matrices in Figure 2 illustrates how actual expenditures could be rolled up to identify the realized strategic lift budget for joint exercises. This

17 In fact, three major modifications to PPB occurred within the Department of Defense in 2002. First, a shift to a two-year cycle was implemented; second, there was a renewed emphasis on up-front decisions (the "Enhanced Planning Process"; SPG; JPG) to provide stronger guidance to the services; third, an "execution" phase was added. While Congress still appropriates the defense budget on an annual basis, DoD now commits to a two-year budget, partly to reduce redundant and costly program reviews. Arguably, the most significant change is that in every even year (or "On-Year" of a two-year cycle), an attempt is now made to accomplish department-wide global optimization at the front end of the process instead of at the back end. That is, an effort is made to make cross-service trade-offs early to guide the production of joint capabilities (outputs), and the corresponding program decisions on platforms and weapon systems (inputs). The theory is that if programs are "born joint" instead of being cobbled together late in the process, this will improve "allocative efficiency" (increasing military effectiveness) and contribute to "operational efficiency" (cutting defense costs).

U.S. Department of Defense, Management Initiative Decision 913, Implementation of a 2Year Planning, Programming, Budgeting and Execution Process (Washington, D.C.: Government Printing Office, 22 May 2003). 
results in an "actual budget" for strategic lift for JEP that can be compared with the "planned budget" to improve future forecasting. The differences that appear between planned and actual budgets for many COCOMs are significant. Revealing these differences could motivate investments to provide near-real-time data streams, and to improve forecasts, so that scarce funds can be released for other pressing activities, such as expanding existing exercises or funding previously unfunded exercises.

Continuously monitoring differences between planned and actual costs (and performance) not only satisfies the spirit of GPRA, but can also help reveal returns on the nation's defense investments. This has the potential to increase accountability, efficiency, and effectiveness within the Department of Defense, and to result in more realistic budget estimates generated by the PPBE process.

\section{Conclusion}

A key challenge that faces federal agencies as they struggle to satisfy GPRA mandates is to adapt conventional business management, measurement, and accounting frameworks to the public sector. The SUCCESS model is designed to help bridge the gap between business and government. Combined with appropriate incentives, implementing a framework with these features could facilitate realization of the three chief aims of GPRA: to improve executive and congressional decision making, to promote better internal management of government programs, and to increase accountability to taxpayers. ${ }^{19}$

19 GPRA 1993: Public Law 103-62. 


\section{THE QUARTERLY JOURNAL}

\section{Bibliography}

Brimson, James A., and Callie Berliner. Cost Management for Today's Advanced Manufacturing . Boston: Harvard Business School Press, 1988.

Johnson, Thomas H., and Robert S. Kaplan. Relevance Lost: The Rise and Fall of Management Accounting. Boston: Harvard Business School Press, 1987.

Kaplan, Robert, and David Norton. "The Balanced Scorecard: Measures that Drive Performance." Harvard Business Review (1992).

Kaplan, Robert, and David Norton. "Using the Balanced Scorecard as a Strategic Management System." Harvard Business Review (1996): 75-85.

Kaplan, Robert, and David Norton. The Strategy Focused Organization . Boston: Harvard Business School Press, 2001.

Melese, Francois, James Blandin, and Sean O'Keefe. "A New Management Model for Government: Integrating Activity-Based Costing, the Balanced Scorecard and Total Quality Management." The International Public Management Review 5, no. 2 (2004): 103-130.

Player, Steve, and Carol Cobble. Cornerstones of Decision Making: Profiles of Enterprise ABM . Greensboro, NC: Oakhill Press, 1999.

Schick, Allen. "The Road to PPB: The Stages of Budget Reform." Public Administration Review (1966).

Senge, Peter. "Looking Ahead: Implications of the Present." Harvard Business Review (1997).

Smith, Ralph. Business Process Management and the Balanced Scorecard: Using Processes as Strategic Drivers. Hoboken, NJ: John Wiley, 2007. 